Original Research Paper

\title{
Sequence Analysis of Scaffold/Matrix Attachment Regions (S/MARs) From Human Embryonic Kidney and Chinese Hamster Ovary Cells
}

\author{
Nur Shazwani Mohd Pilus, Azrin Ahmad and Nurul Yuziana Mohd Yusof \\ Faculty of Science and Technology, Universiti Kebangsaan Malaysia, Bangi, Malaysia
}

\author{
Article history \\ Received: 21-08-2018 \\ Revised: 05-09-2018 \\ Accepted: 25-09-2018 \\ Corresponding Author: \\ Nur Shazwani Mohd Pilus \\ Faculty of Science and \\ Technology, Universiti \\ Kebangsaan Malaysia, 43600 \\ UKM Bangi, Malaysia \\ Email: shazwani.pilus@gmail.com
}

\begin{abstract}
Binding of intergenic Scaffold/Matrix Attachment Regions (S/MARs) to nuclear matrix proteins is believed to poise adjacent genes for transcription by forming chromatin loops. Vector constructs containing Scaffold/Matrix Attachment Regions (S/MAR) flanking the gene of interest, therefore, are able to enhance recombinant protein expression in mammalian cells. We compared two methods that are based on buffers containing $2 \mathrm{M} \mathrm{NaCl}$ and Lithium-3,5-diidosalicylate (LIS) to isolate S/MARs from HEK293 and CHO DG44 cell lines. Isolated S/MARs were sequenced using the Illumina HiSeq platform and mapped against $\mathrm{CHO}$ DG44 genome contigs and the human genome GRCh37.p13 respectively (Sequence raw data from this article have been deposited at the EMBL Data Libraries under Study ID PRJEB26090 (ERP108063)). The 2M $\mathrm{NaCl}$ method produced 16 million $\mathrm{S} / \mathrm{MAR}$ consensus sequences which included nine million and seven million from HEK293 and CHO DG44 respectively. LIS method, on the other hand, generated thirteen million S/MAR consensus containing 8.4 million and 4.7 million from HEK293 and CHO DG44, respectively. In order to compare all sets of S/MAR consensus, BLASTN analyses were performed based on exact matches. The number of perfect matches between S/MAR sequences produced by both methods was quite low: $0.46 \%$ and $0.07 \%$ for HEK293 and CHO DG44 cells respectively, indicating that the two methods isolate different sets of S/MARs. Comparison between the two cell lines found six S/MARs in common, with average coverage of $82 \%$, obtained by the $2 \mathrm{M} \mathrm{NaCl}$ method, but none of these are intergenic. The LIS method gave $38 \mathrm{~S} /$ MARs with average coverage of $85 \%$, common to both cell types; of these, 13 were intergenic. We hypothesize that S/MARs from HEK293 and CHO DG44 isolated using the LIS method have the potential to be universal vector expression elements that can overcome the problem of low production yield.
\end{abstract}

Keywords: $2 \mathrm{M} \mathrm{NaCl}$, LIS, Intergenic, Gene Transcription, Biopharmaceutical, Expression Vector

\section{Introduction}

In the era of modern medicine, recombinant protein therapeutics are contributing significantly to innovative and effective therapies for treatment of numerous human diseases (Agarwal et al., 1998). Therapeutic proteins such as antibodies and enzymes, produced in mammalian cells, have been successfully utilized in the treatment of diseases in the past decade. Gene transfer technology in mammalian cells - particularly in cells engineered for production of proteins - requires sustainable and high level expression. However, the positional effect of transgene integration sites might hinder the effectiveness of the recombinant protein expression in the transfected cells. This factor could be due to the influences of the chromatin structure effects and/or dominant regulatory elements flanking the integration sides of the gene (Feng et al., 2001). One of the strategies to overcome this effect is 
by adapting scaffold or matrix attachment regions, S/MARs, in the expression vectors (Allen et al., 2005; Argyros et al., 2011).

The terms scaffold and matrix referring to the same biological entities, which are proteins structuring the nucleus, but these two were differentiated by two different isolation methods (Bode and Maass, 1988; Donev, 2000). The Matrix Attachment Region (MAR), was introduced by Berezney and Coffey (1974), after their discovery of fibrous protein structures in the nucleus known as Matrix Proteins (MPs). Both MARs and MPs were attained by isolating nuclei using a buffer of $\mathrm{NaCl}$, detergent and enzymes; the $\mathrm{NaCl}$ helps to disrupt histone/DNA interactions by competing for binding sites on the DNA (Earnshaw and Laemmli, 1983), but some have argued that this creates artifacts due to precipitation under high salt conditions (Berezney and Coffey, 1974). Later, Mirkovitch et al. (1984) introduced an isolation method that reduced the artifacts using a low concentration of Lithium-3, 5diiodosalicylate (LIS) in place of the high salt (Mirkovitch et al., 1984); the LIS acts as an anionic salt that lowers the ionic strength and reduces the flexibility of DNA which, along with charge repulsions, displaces it from the histones (Marky and Manning, 1991). Hence, the DNA fractions attached to a scaffold protein isolated using LIS method were referred as Scaffold Attachment Region (SAR). As S/MARs bind to nuclear proteins, they are associated with important biological roles particularly in genome organization (Berezney et al., 1995; Bode et al., 2006; Manuelidis, 1990), gene transcription stabilization (Cockerill and Garrard, 1986) and assisting genome replication (Bode et al., 1996).

$\mathrm{S} / \mathrm{MARs}$ have been implicated in the regulation of gene expression due to their co-localization with the transcription units and regulatory elements in genomes (Bode et al., 2000). S/MARs are believed to regulate gene expression by initiating interactions between DNA activating complexes and genes and also by controlling chromatin accessibility (Heng et al., 2004). They act by forming loops that poise specific regions of the genome for transcription (Bode et al., 1996; Jackson, 1997; Razin, 2001). As S/MARs could be directly involved in the regulation of the gene expression at the chromatin structure level, it is believed that the use of these elements in expression vectors might aid high level production of protein in host cells (Girod et al., 2005). However, it is crucial to investigate the function of S/MARs, which have the potential to either up- or down regulate gene expression and such information on the relationship between $\mathrm{S} / \mathrm{MARs}$ and gene regulation is still in deliberation.

Based on the 2009 chromosome-level study by Linnemann et al. on HeLa cells' chromosome 16, SARs located at 5' of a gene are associated with the expressed transcripts while MARs positioned within a gene are related to gene silencing (Linnemann et al., 2009). These varied functions of S/MARs were discovered based on comparison of two different extraction methods. LIS extraction will disrupt binding mediated through transcription complexes to yield nuclear scaffold (Bode et al., 1996), whereas $2 \mathrm{M} \mathrm{NaCl}$ extraction is suggested to isolate a nuclear matrix that is interwoven with newly synthesized RNA (Ma et al., 1999). Integrated information based on analysis of the DNA regions from these two methods and gene expression profiling demonstrated that SARs at 5' of genes are related to highly expressed transcripts and genes attached to the intergenic MARs are silent (Linnemann et al., 2009). Thus, it is feasible that S/MARs could enhance the expression of a gene which they flank. However, not many studies have been carried out to assess regions of matrix association throughout the genome.

At the beginning era of high-throughput sequencing technology using combination of DNA library construction and Sanger's sequencing method, a genomic array-based analysis using large insert library clones from a human genomic library was performed to identify S/MARs extracted by LIS method. A total of 2.5 Mbp S/MARs were mapped to a human neocentromer imparted the centromer's function in nuclear organization during mitosis and meiosis (Sumer et al., 2003). As the sequencing technology advanced to next generation approaches, an improved method of identifying S/MARs from Drosophila melanogaster was accomplished. A total of $7353 \mathrm{~S} / \mathrm{MARs}$ were isolated using LIS method and were sequenced by SOLiD platform (LifeTech, USA). Through intensive genome wide analysis, these S/MARs were found to represent $2.6 \%$ of the genome and were recognized as DNA elements associated with transcription sites of highly expressed genes (Pathak et al., 2014).

While the information for a genome-wide study has not been established for mammalian cells, our study aims to identify S/MAR sequences based on both LIS (Keaton et al., 2011) and $\mathrm{NaCl}$ (Krawetz et al., 2005) extraction methods for two different mammalian cell lines, CHO DG44 and HEK 293, at genome level using the Solexa sequencing platform (Illumina Incorporation, USA). Sequences of the isolated S/MARs were generated and mapped to respective genome data. Clustering analysis between the two datasets of S/MAR sequences from the two mammalian cell lines was performed to narrow down the S/MAR dataset based on sequence similarities. These shortlisted S/MAR sequences were identified for their location in the genome, either intergenic or intragenic. Hopefully, such information could provide a better understanding of S/MARs, to enable a strategy for genetic intervention to produce a better host cell line, better downstream culture environments or a better expression vector. Such improvements may lead to higher yields and this greater affordability, of therapeutic proteins. 


\section{Materials and Methods}

\section{Cell Culture}

CHO DG44 and HEK293 cell lines were obtained courtesy of Inno Biologics Sdn. Bhd. and cell preparation subjected to human is conformed to the principles outlined in the Declaration of Helsinki. CHO cells were cultured in HyClone $^{\mathrm{TM}} \mathrm{SFM} 4 \mathrm{CHO}^{\mathrm{TM}}$ (Thermo Scientific, USA) while HEK293 cells were cultured in 293 SFM II (Invitrogen, USA). Both cells were cultured in spinner flask with agitation at $45 \mathrm{rpm}$ until they reached $\log$ phase. An amount of $7 \times 10^{6}$ cells $/ \mathrm{ml}$ were harvested for S/MAR isolation using $2 \mathrm{M}$ $\mathrm{NaCl}$ and another $1 \times 10^{6}$ cells $/ \mathrm{ml}$ for isolation using lithium-3,5-diiodosalicylate (LIS). Medium was removed and cell pellet were washed using 1X PBS buffer pH7.4 supplemented with protease inhibitor (Roche, USA). One tablet of protease inhibitor was added into each $10 \mathrm{~mL}$ of PBS buffer.

\section{$2 \mathrm{M} \mathrm{NaCl}$ Isolation Method}

\section{Halo in Gel}

S/MAR isolation using $2 \mathrm{M} \mathrm{NaCl}$ was done in two parts. The first part known as halo in gel is required to determine the minimum time taken for cell nuclei to form the largest halo size within incubation period between 1 and $10 \mathrm{~min}$, at one-minute interval. Nuclear halo is characterized as an overlapping chromatin strand anchored to matrix protein by means of S/MAR after depletion of histones (Krawetz et al., 2005).

A total of 11 slides containing a layer of $0.5 \%$ $(\mathrm{w} / \mathrm{v})$ low-melting agarose gel mixed with approximately $6 \times 10^{4}$ cells per slide were prepared to test the incubation time with halo buffer. Encapsulated cells were treated with nuclei buffer for 1 hour on ice to isolate nucleus. Cell nuclei were washed using PBS buffer pH 7.4 supplemented with protease inhibitor for $1 \mathrm{~min}$. Each of 10 slides was dedicated for incubation in halo buffer containing $2 \mathrm{M}$ $\mathrm{NaCl}$ for every $1 \mathrm{~min}$ starting from 1 to $10 \mathrm{~min}$. One slide is reserved for negative control. To stop the reaction of halo buffer, slides were dipped in 1X PBS buffer $\mathrm{pH} 7.4$ supplemented with protease inhibitor for $1 \mathrm{~min}$. To fix the nuclei on gel, a cold absolute ethanol were applied and slides were dried at $55^{\circ} \mathrm{C}$ for $30 \mathrm{~min}$. Halo image were visualized using fluorescent microscope after staining with $100 \mu \mathrm{g} / \mathrm{ml}$ ethidium bromide. Six halos were randomly captured for each incubation time to get an average halo size. The size is obtained after subtracting the outmost area with the inner area using ImageJ V1.50i software (Fig. 1). A time point with largest area difference was the most convenient incubation time to induce halo structure for a particular cell type.

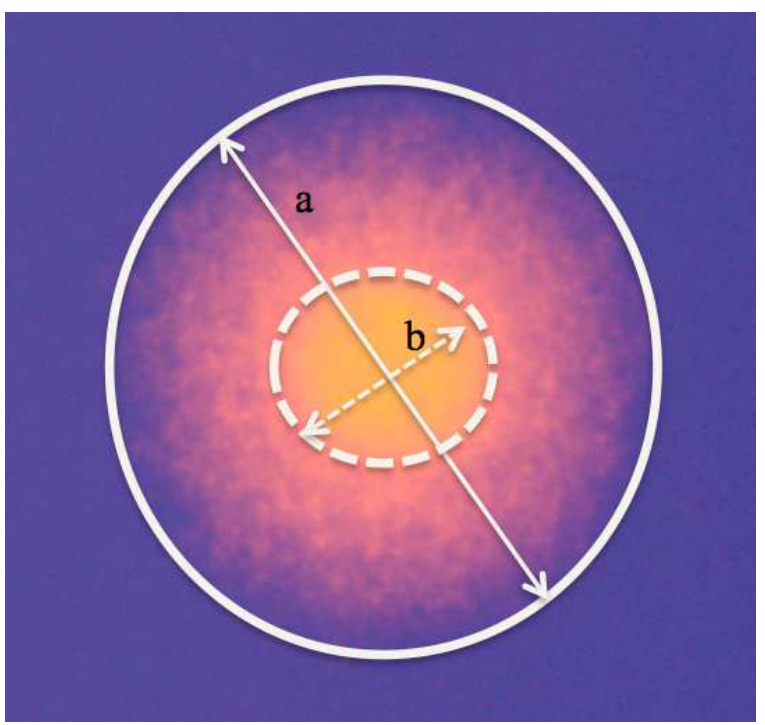

Fig. 1: Halo size is determined by subtracting the outer area (a) with inner area (b)

\section{Halo in Solution}

The procedure of nuclei isolation is repeated in this second part of isolation but extraction is done in solution. The time obtained from halo in gel method is applied for incubation in buffer containing $2 \mathrm{M} \mathrm{NaCl}$ to induce nuclei halo formation. An amount of $7 \times 10^{6}$ cells $/ \mathrm{mL}$ was harvested and medium was removed by centrifugation at 65 $\mathrm{x} g$ for CHO DG44 and $200 \mathrm{x}$ g for HEK293 cells for $7 \mathrm{~min}$ at $4^{\circ} \mathrm{C}$. Pellet was resuspend in $2 \mathrm{~mL} 1 \mathrm{X}$ PBS buffer $\mathrm{pH} 7.4$ supplemented with $1 \mathrm{mg} / \mathrm{ml}$ Bovine Serum Albumin (BSA) (Amresco, USA) and protease inhibitor and centrifuged at respective speeds for $7 \mathrm{~min}$ at $4^{\circ} \mathrm{C}$. Pellet was resuspend in $2 \mathrm{~mL}$ nuclear buffer $(10 \mathrm{mM}$ Tris- $\mathrm{HCl} \mathrm{pH} 7.7,100 \mathrm{mM}$ $\mathrm{NaCl}, 300 \mathrm{mM}$ sucrose, $3 \mathrm{mM} \mathrm{MgCl} 2,0.5 \%$ (v/v) Triton-X 100 , protease inhibitor) for 1 hour on ice to isolate nucleus. Cell nuclei were collected by centrifugation at respective speeds for $7 \mathrm{~min}$ at $4^{\circ} \mathrm{C}$. Pelleted nuclei were washed with $2 \mathrm{~mL}$ 1X PBS pH 7.4 supplemented with protease inhibitor and centrifuged at respective speeds for $7 \mathrm{~min}$ at $4^{\circ} \mathrm{C}$. Pellet was resuspend with $2 \mathrm{~mL}$ halo buffer $(10 \mathrm{mM}$ Tris-HCl pH7.7, 10 mM EDTA, $2 \mathrm{M} \mathrm{NaCl}, 1$ mM DTT) and incubation was done on ice with the duration of $8 \mathrm{~min}$ for CHO DG44 and 7 min for HEK293 as per determined from halo in gel procedure. A total of $40 \mathrm{~mL}$ restriction enzyme buffer (50 mM Tris- $\mathrm{HCl} \mathrm{pH} 8.0,10 \mathrm{mM} \mathrm{MgCl}$ ) were added to the nuclei solution and centrifuged at $200 \mathrm{xg}$ for both cell lines for $7 \mathrm{~min}$ at $4^{\circ} \mathrm{C}$. An amount of $1 \mathrm{~mL}$ supernatant was reserved in tube for digestion with 100 $\mathrm{U} E c o \mathrm{RI}$ and $100 \mathrm{U}$ BamHI. Incubation was done at $37^{\circ} \mathrm{C}$ for $4 \mathrm{~h}$ with agitation at $110 \mathrm{rpm}$. To separate S/MAR from genomic DNA, nucleus was centrifuged at $16,000 \mathrm{xg}$ for $5 \mathrm{~min}$ at $4^{\circ} \mathrm{C}$. Supernatant was labeled as loop fraction. A volume of $300 \mu \mathrm{L}$ proteinase $\mathrm{K}$ 
buffer (50 mM Tris-HCl pH8.0, $50 \mathrm{mM} \mathrm{NaCl}, 25 \mathrm{mM}$ EDTA, $0.5 \%$ (v/v) SDS, $120 \mu \mathrm{g}$ proteinase K enzyme) were added to each pellet and supernatant fractions. $\mathrm{S} / \mathrm{MAR}$ were recovered after overnight incubation with proteinase $\mathrm{K}$ enzyme at room temperature.

\section{LIS Isolation Method}

A total of $7 \times 10^{6}$ cells/ml CHO DG44 and HEK293 were harvested and medium were removed by centrifugation at $65 \mathrm{x}$ g for CHO DG44 and $200 \mathrm{xg}$ for HEK293 for $5 \mathrm{~min}$ at $4^{\circ} \mathrm{C}$. Pellet was washed with $2 \mathrm{~mL}$ PBS buffer supplemented with $0.1 \mathrm{mM}$ PMSF. Centrifugation was done as previously mentioned speed for $5 \mathrm{~min}$. Cell pellet were resolved with $2 \mathrm{~mL}$ lysis buffer (50 mM KCl, $0.5 \mathrm{mM}$ EDTA, $0.05 \mathrm{mM}$ spermine, $0.125 \mathrm{mM}$ spermidine, $1 \mathrm{mM}$ DTT, $0.1 \% \quad(\mathrm{w} / \mathrm{v})$ digitonin, $0.5 \mathrm{mM}$ Tris- $\mathrm{HCl}, 0.1 \mathrm{mM}$ PMSF) and 1.25 volume of stabilization buffer $(50 \mathrm{mM} \mathrm{KCl}, 0.625 \mathrm{mM}$ $\mathrm{Cu}_{2} \mathrm{SO}_{4}, 0.05 \mathrm{mM}$ spermine, $0.125 \mathrm{mM}$ spermidine, 1 $\mathrm{mM}$ DTT, 0.1\% (w/v) digitonin, $0.5 \mathrm{mM}$ Tris-HCl, 0.1 $\mathrm{mM}$ PMSF) prior to incubation on ice for $20 \mathrm{~min}$. After $20 \mathrm{~min}, 10 \mathrm{ml}$ LIS buffer $(10 \mathrm{mM}$ LIS, $100 \mathrm{mM}$ $\mathrm{C}_{2} \mathrm{H}_{3} \mathrm{LiO}_{2}, 0.05 \mathrm{mM}$ spermine, $0.125 \mathrm{mM}$ spermidine, 1 $\mathrm{mM}$ DTT, $0.05 \%$ (w/v) digitonin, $20 \mathrm{mM}$ HEPES-KOH pH7.4) was added and mixture was left to stand at room temperature for $10 \mathrm{~min}$. To separate nuclei, mixture was centrifuged at $2620 \mathrm{x}$ g for $35 \mathrm{~min}$. Supernatant was carefully removed and $2 \mathrm{~mL}$ of matrix washing buffer $(20 \mathrm{mM} \mathrm{KCl}, 70 \mathrm{mM} \mathrm{NaCl}, 10 \mathrm{mM} \mathrm{MgCl}, 20 \mathrm{mM}$ Tris$\mathrm{HCl} \mathrm{pH7.4)}$ were added resolved pellet. Mixture was centrifuged at $2620 \mathrm{x} \mathrm{g}$ for $35 \mathrm{~min}$. Pellet was washed twice with restriction buffer $(50 \mathrm{mM} \mathrm{NaCl}, 10 \mathrm{mM}$ $\mathrm{MgCl}_{2}, 100 \mathrm{mM}$ Tris-HCl 7.4) and centrifuged at $2620 \mathrm{x}$ $\mathrm{g}$ for $35 \mathrm{~min}$ at each wash. To separate S/MAR from genomic DNA, $1 \mathrm{~mL}$ of restriction buffer $(50 \mathrm{mM} \mathrm{NaCl}$, $10 \mathrm{mM} \mathrm{MgCl}_{2}, 100 \mathrm{mM}$ Tris-HCl pH7.4, $0.025 \%$ (v/v) Triton X-100) was added to nuclei pellet. A concentration of $100 \mathrm{U}$ EcoRI and $100 \mathrm{U}$ BamHI were added to the solubilized pellet and incubated at $37^{\circ} \mathrm{C}$ for $1.5 \mathrm{~h}$ with $110 \mathrm{rpm}$ agitation. Mixture was centrifuged at $2620 \mathrm{x}$ g for $10 \mathrm{~min}$ and supernatant were saved as loop fraction. Another $1 \mathrm{ml}$ of restriction buffer with EcoR1 and BamHI were added to nuclei pellet and incubation was continued for another 1 hour. At minutes 45, 20 $\mu \mathrm{g} / \mathrm{ml}$ RNase A was added and incubation continued until minutes 60. Mixture was centrifuged at $2620 \mathrm{x} \mathrm{g}$ for $10 \mathrm{~min}$ and supernatant was mixed with $300 \mathrm{mM}$ $\mathrm{NaCl}$ and $27 \mathrm{mM}$ EDTA to preserved the DNA. To digest the bounded protein on S/MAR, pellet was solubilized with $1 \mathrm{~mL}$ of $\mathrm{K} 1$ buffer $(300 \mathrm{mM} \mathrm{NaCl}, 2.5$ mM EDTA, $10 \mathrm{mM}$ Tris-HCl pH8.0) followed by $2 \mathrm{~mL}$ of proteinase $\mathrm{K}$ buffer (1\% Nlaurylsarcosine, $450 \mathrm{mM}$ $\mathrm{NaCl}, 45 \mathrm{mM}$ EDTA, $60 \mathrm{mM}$ Tris-HCl pH8.0, 120 $\mu \mathrm{g} / \mathrm{ml}$ Proteinase K enzyme) and incubated overnight at room temperature. S/MAR in pellet and loop fractions collected from $2 \mathrm{M} \mathrm{NaCl}$ and LIS methods were purified using phenol:chloroform:isoamylalcohol (25:24:1) (Chomczynski and Sacchi, 1987).

\section{Quantity and Quality Analysis of S/MAR}

Quantity was measured using spectrophotometer NanoDrop ND (Thermo Fisher Scientific, USA) for S/MAR extracted using both methods. Purified S/MARs extracted using $2 \mathrm{M} \mathrm{NaCl}$ were analyzed using Bioanalyzer (Agilent Technologies, USA) while purified S/MARs extracted using LIS were analyzed using $1 \%$ electrophoresis agarose gel.

\section{Sample Preparation for NGS Sequencing}

Sample preparation for sequencing using NGS HiSeq 2000 platform was performed according to Nextera XT DNA kit manual (Illumina Incorporation, USA). A total of $1 \mathrm{ng}$ of S/MAR sample was used as starting material for paired-end sequencing. Sequencing was outsourced to Malaysia Genome Institute and completed after 2 weeks.

\section{Data Analysis}

\section{Trimming Sequencing Reads}

Post NGS sequencing data was trimmed using SolexaQA software package to eliminate any low quality reads. A cut off value of Qphred 20 was set to obtain at least 99\% sequence target using DynamicTrim and any reads with length lower than 50 bp were removed using LengthSort. Every sequencing pair was determined and any unpaired reads were kept separately as singletons. Both paired reads and singletons of HEK293 S/MAR were mapped against human genome GRCh37.p13 (www.gencodes.org/releases/19.html) using CLC Genomic Workbench 7.0 to generate consensus sequences. Meanwhile, CHO DG44 S/MAR was mapped against CHO DG44 contigs since the genome is currently developing.

\section{S/MAR Matched Sequence Search Against Loop Fractions}

Both isolation methods have produced loop fractions resulting from the restriction enzyme degradation that separated them from matrix or scaffold fractions. All four loop-fractions were sequenced together with respective $\mathrm{S} / \mathrm{MAR}$ fractions. The loop consensus was then BLAST with respective S/MAR fractions using BLASTN 2.2.28 program. E value cut off was set to zero to limit search for only exact sequence hit.

\section{S/MAR Matched Sequence Search Across Two Methods}

S/MAR consensus sequence of HEK293 and CHO DG44 isolated using $2 \mathrm{M} \mathrm{NaCl}$ were BLAST against $\mathrm{S} / \mathrm{MAR}$ isolated using LIS to search for any matched 
sequence obtained by both methods. Sequence comparison was done according to cell line using the same program and parameter settings.

\section{S/MAR Matched Sequence Search Across Two Cell Lines}

S/MAR isolated from HEK293 were BLAST using the same program and parameter settings against S/MAR isolated from $\mathrm{CHO}$ DG44 to search for any shared sequences across these two cell lines.

\section{Mapping of HEK293-CHO DG44 S/MAR against Annotated Human Genome}

Matched sequence from BLAST result across two cell lines were mapped against annotated human genome Patch 13 (NCBI) using CLC Genomic Workbench 6.0.2 to locate the position of shared HEK293 and CHO DG44 S/MAR. To get the detailed identity of mapped S/MAR, the consensus sequences were BLAST using nonredundant (nr) database with zero E value cut off.

\section{S/MAR Matched Sequence Search against Annotated Protein}

BLASTX analysis among S/MAR consensus were performed against annotated protein database from CHO K1 (www.chogenome.org) since our CHO DG44 database is still under construction. Meanwhile, S/MAR consensus from HEK293 were analyzed based on human genome database GRCh37.p13 (www.gencodes.org/releases.19.html). Both BLAST analysis was set to E-value cut off at $10^{-10}$ to produce more stringent result using BLASTX 2.2.30+.

\section{Results}

\section{Isolation of $S / M A R S$}

Potential S/MARs isolated using both the $2 \mathrm{M} \mathrm{NaCl}$ and LIS methods were quantified using a Nanodrop spectrophotometer. Quality assessment was determined by $1 \%(\mathrm{w} / \mathrm{v})$ agarose gel electrophoresis for DNA samples extracted using LIS method. Due to the low yield, DNA samples obtained from the $2 \mathrm{M} \mathrm{NaCl}$ method were analysed on a Bioanalyzer (Agilent, USA) (refer Supplementary Materials). The percentages of DNA recovered in the S/MAR (attached) and loop (nonattached) fractions were determined in order to evaluate the distribution of both fractions after being isolated by these two methods (Table 1). For the $2 \mathrm{M}$ $\mathrm{NaCl}$ method, the fraction of DNA in the S/MAR fraction $(26 \%$ and $37 \%$ for $\mathrm{HEK}$ and $\mathrm{CHO}$ cells, respectively) was similar to a previous study which found about $30 \%$ to $40 \%$ of DNA is recovered in this fraction using $2 \mathrm{M} \mathrm{NaCl}$ (Boulikas, 1995). LIS extraction has lower percentage of S/MAR, 3.2\% and $2.7 \%$ for
HEK293 and CHO DG44, respectively. This result might due to cleavage by restriction enzymes being more efficient in the LIS method compared to $\mathrm{NaCl}$ method. This, in turn, may be because of DNA structural changes in high salt, affecting the site-recognition of EcoRI and BamHI (Travers, 1993).

\section{Next Generation Sequencing of S/MARs}

This study is the first report of sequencing of the $\mathrm{S} / \mathrm{MAR}$ fragments from both LIS and $\mathrm{NaCl}$ isolation methods from mammalian cell lines using the Solexa platform (Illumina Incorporation, USA). The libraries were prepared using the Nextera XT DNA kit (Illumina Incorporation, USA) and the sequencing was performed as paired-end, which is an advantage for alignment accuracy (Quinlan et al., 2010). From the total of all S/MARs' reads, at least $79 \%$ of them were considered as high quality reads (data not shown). The percentage of $\mathrm{S} / \mathrm{MAR}$ reads mapped against the respective human genome and CHO DG44 genome contigs (Ahmad, 2016) using CLC Genomic Workbench software analysis ranges between $91.8 \%$ and $99.5 \%$ (Table 2).

\section{Sequence Analysis of S/MAR Data}

The loop DNA fractions were sequenced together with respective S/MAR fractions to examine the effectiveness of both methods in capturing S/MARs that were interacting with matrix protein hence, being least contaminated by loop DNA. Although S/MARs are present throughout the genome, not every S/MAR will interact with matrix protein all of the time to form loop: Interactions depend on cell cycle stage and cell type at the time S/MAR isolation was performed (Barboro et al., 2012; Boulikas, 1995). BLASTN analyses were performed to compare sequences between S/MAR fractions and loop DNA fractions. For NaCl-isolated S/MAR from HEK293, BLASTN analysis showed a low percentage (0.13\%; $22,839 / 17,215,861)$ of matched sequences while for CHO DG44 0.32\% $(45,828 / 14,157,742)$ were matched. For LIS-isolated material, matches between S/MAR and loop fractions were even lower; that is $0.07 \%$ $(10,083 / 14,960,547)$ from HEK cells and $0.13 \%$ $(14,837 / 11,607,655)$ from $\mathrm{CHO}$ (Fig. 2). These results suggest that both methods achieve a very clean partitioning between S/MAR and loop DNA.

It has been claimed that some S/MARs may involved in either gene silencing or gene activating, depending on the isolation method used (Donev, 2000; Linnemann et al., 2009). The location of S/MAR in the genome, whether they flanked a gene or located in between genes, influenced its property and it also has close relationship with the isolation method used (Dijkwel and Hamlin, 1988). Thus, in this study, BLASTN analysis was performed between $2 \mathrm{M} \mathrm{NaCl}$ and 
LIS S/MAR consensus sequences, to see whether the same sequences were isolated by both methods. There were only $0.46 \% \quad(80,807 / 17,407,528)$ and $0.07 \%$ $(8340 / 11,877,261)$ sequence matches between the $\mathrm{NaCl}$ and LIS datasets for HEK293 and CHO DG44 cells, respectively (Fig. 3). This indicates that the two methods isolate different and largely non-overlapping, populations of sequence.

We also used BLASTN analysis to look for S/MARs, which were common to both cell types, using each of the two methods. There are only six and 38 consensus sequences in common between the two cell types, the $\mathrm{NaCl}$ and LIS isolation methods, respectively (Fig. 4). This is not unexpected, given that the two cell lines are from different species (Chinese hamster and human) and there are also different cell types with different expression profiles. However, the 44 S/MARs shared between the two cell lines could become a potential element in expression vectors to be applied across different types of mammalian cell line (Table 3 to 5).
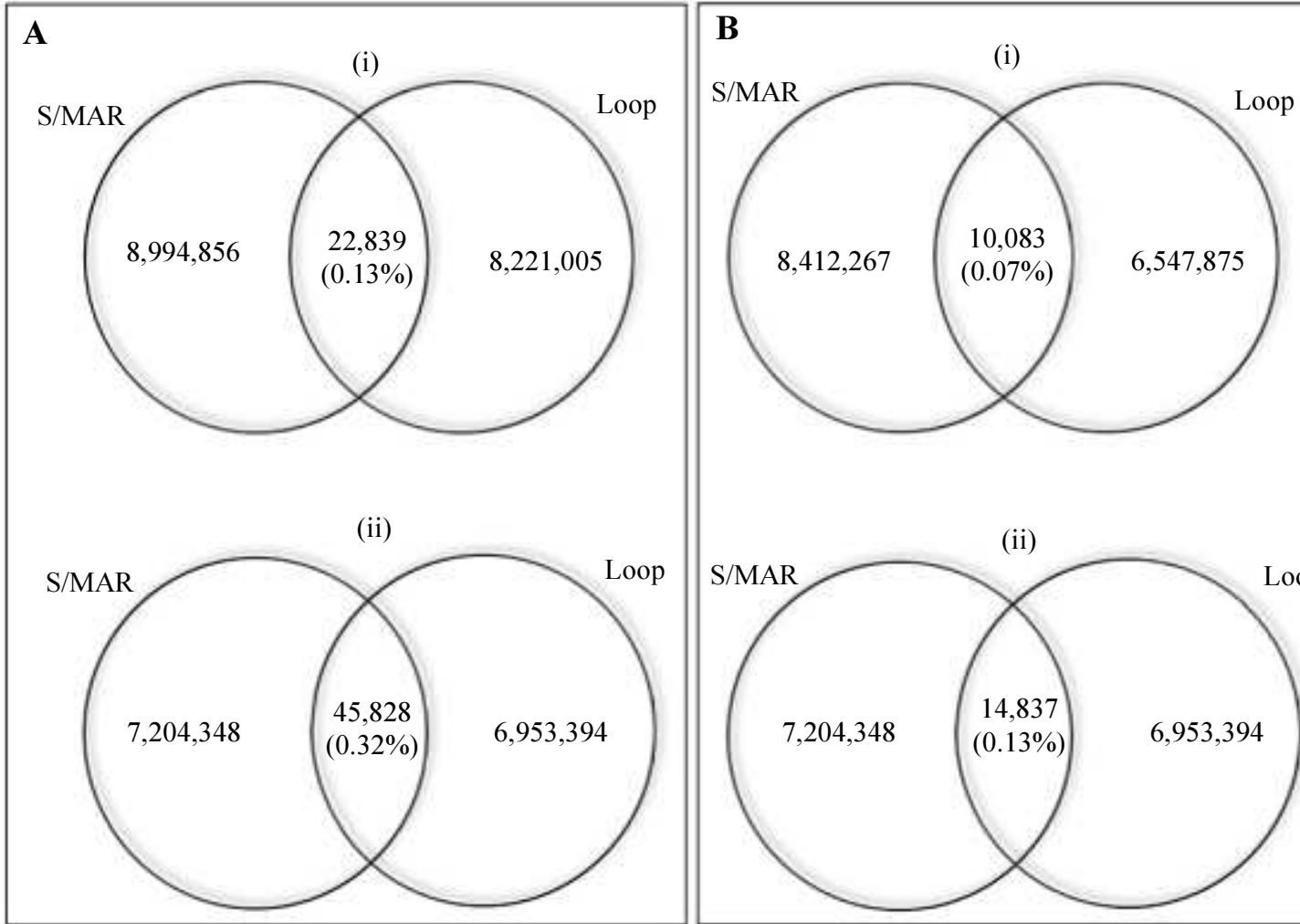

(ii)

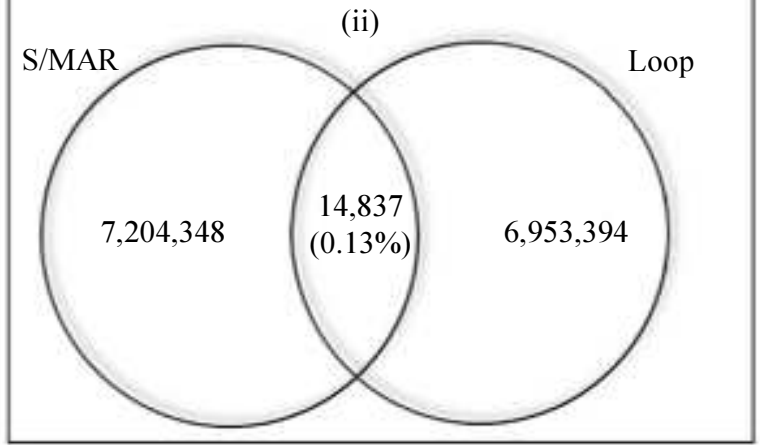

Fig. 2: BLAST result for matched sequence search between S/MAR fractions and loop fractions. A(i) is HEK293, A(ii) is CHO DG44 both from $\mathrm{NaCl}$ method and $\mathrm{B}(\mathrm{i})$ is HEK293, B(ii) is CHO DG44 both from LIS method
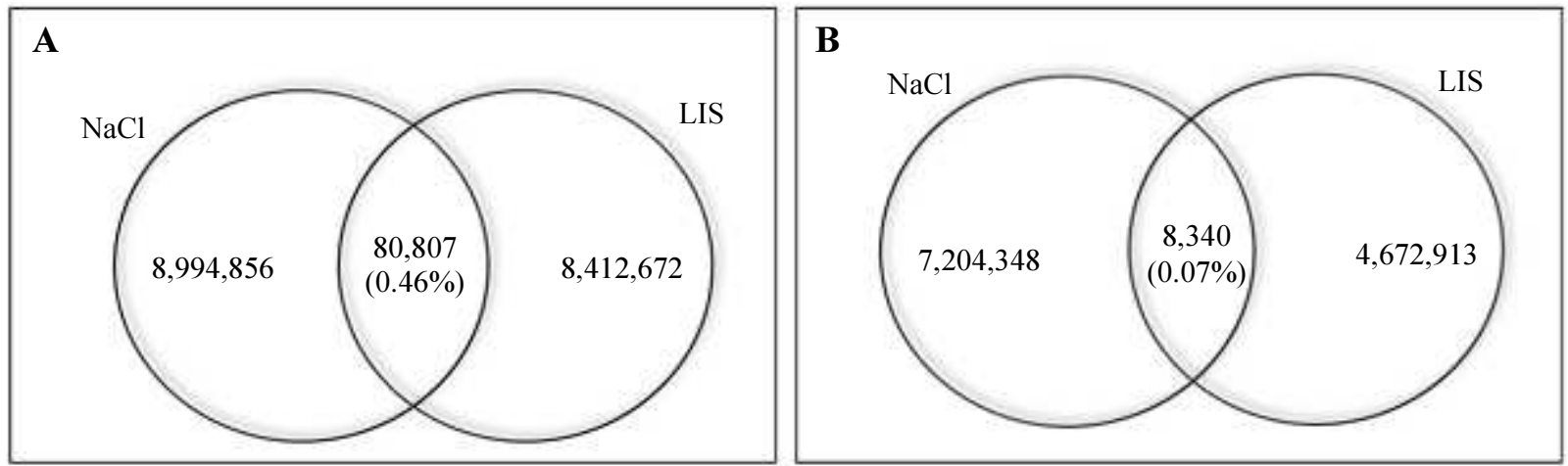

Fig. 3: BLAST result for matched sequence search between two different methods. (A) S/MAR isolated from HEK293 and (B) S/MAR isolated from CHO DG44 

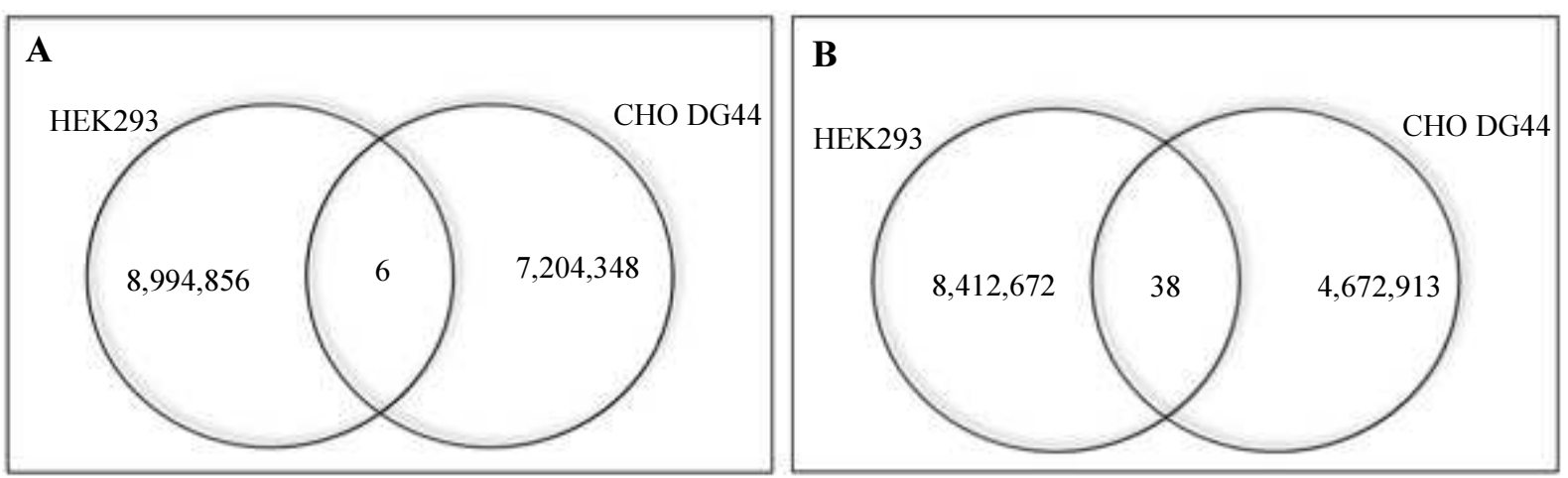

Fig. 4: BLAST result for sequence similarity search between two different cell lines. (A) NaCl-isolated S/MAR and (B) LISisolated S/MAR

Table 1: Quantitative analysis of HEK293 and CHO DG44 S/MAR using spectrophotometer

\begin{tabular}{lllcccc}
\hline $\begin{array}{l}\text { Isolation } \\
\text { method }\end{array}$ & Cell line & Fractions & Quantity $(\mu \mathrm{g})$ & $\begin{array}{c}\text { Percentage of } \\
\text { DNA fraction (\%) }\end{array}$ & $\mathrm{A}_{260 / 280}{ }^{\mathrm{b}}$ & $\mathrm{A}_{260 / 230} \mathrm{c}^{\mathrm{c}}$ \\
\hline $\mathrm{NaCl}$ & HEK293 & S/MAR & 0.98 & 26.1 & 1.91 & 2.17 \\
& & Loop DNA & 2.76 & 73.9 & 1.89 & 2.10 \\
& CHO DG44 & S/MAR & 1.31 & 37.1 & 1.88 & 2.09 \\
& & Loop DNA & 2.22 & 62.9 & 2.05 & 2.32 \\
LIS & HEK293 & S/MAR & 1.50 & 3.2 & 1.95 & 2.16 \\
& & Loop DNA & 45.73 & 96.8 & 1.82 & 2.36 \\
& CHO DG44 & S/MAR & 0.66 & 2.7 & 1.67 & 1.78 \\
& & Loop DNA & 23.70 & 97.3 & 1.88 & 2.38 \\
\hline
\end{tabular}

${ }^{a}$ Percentage of DNA fraction was obtained based on below formula: Quantity of S/MAR x $100 \%$

(quantity of S/MAR fraction + quantity of loop DNA fraction)

${ }^{\mathrm{b}}$ Ratio of light absorption at $260 \mathrm{~nm}$ wavelength to light absorption at $280 \mathrm{~nm}$ wavelength

${ }^{\mathrm{c}}$ Ratio of light absorption at $260 \mathrm{~nm}$ wavelength to light absorption at $230 \mathrm{~nm}$ wavelength

Table 2: Number of S/MAR consensus sequences generated after mapping

\begin{tabular}{|c|c|c|c|c|}
\hline Isolation method & Cell line & Mapped reads & $\begin{array}{l}\text { Percentage of } \\
\text { mapped reads }(\%)\end{array}$ & $\begin{array}{l}\text { Total consensus } \\
\text { sequences }\end{array}$ \\
\hline \multirow[t]{2}{*}{$\mathrm{NaCl}$} & HEK293 & $25,091,274$ & 99.5 & $8,994,856$ \\
\hline & CHO DG44 & $24,100,613$ & 91.8 & $7,204,348$ \\
\hline \multirow[t]{2}{*}{ LIS } & HEK 293 & $74,264,342$ & 92.7 & $8,412,672$ \\
\hline & CHO DG44 & $32,214,332$ & 97.6 & $4,672,913$ \\
\hline
\end{tabular}

Table 3: Genes associated with NaCl-isolated S/MAR (CHO DG44-HEK293)

\begin{tabular}{|c|c|c|c|c|}
\hline $\begin{array}{l}\text { Genes associated } \\
\text { with S/MAR }\end{array}$ & S/MAR ID & Protein coded & Protein function & Source \\
\hline ARHGAP5 & S/MAR_HC_N_TRA01 & $\begin{array}{l}\text { Homo sapiens Rho GTPase } \\
5 \text { activated protein }\end{array}$ & $\begin{array}{l}\text { GTPase-activating protein for Rho } \\
\text { family members }\end{array}$ & www.uniprot.org \\
\hline MATR3 & S/MAR_HC_N_TRA02 & Matrin-3 & $\begin{array}{l}\text { Play a role in transcription or interact } \\
\text { with nuclear matrix protein to form } \\
\text { internal fibrogranular network }\end{array}$ & www.uniprot.org \\
\hline EHBP1 & S/MAR_HC_N_TRA03 & EH domain-binding protein 1 & Play a role in actin reorganization & www.uniprot.org \\
\hline SOX6 & S/MAR_HC_N_TRA04 & Transcription factor SOX-6 & $\begin{array}{l}\text { Transcriptional activator and play a } \\
\text { role in several developmental process }\end{array}$ & www.uniprot.org \\
\hline ENAH & S/MAR_HC_N_TRA05 & Protein enabled homolog & $\begin{array}{l}\text { Induces the formation of actin } \\
\text { rich outgrowths in fibroblast }\end{array}$ & www.uniprot.org \\
\hline ZFP62 & S/MAR_HC_N_TRA06 & $\begin{array}{l}\text { Zinc finger protein } 62 \\
\text { homolog }\end{array}$ & $\begin{array}{l}\text { Play a role in differentiating } \\
\text { skeletal muscle }\end{array}$ & www.uniprot.org \\
\hline
\end{tabular}


Nur Shazwani Mohd Pilus et al. / OnLine Journal of Biological Sciences 2018, 18 (4): 387.400 DOI: 10.3844/ojbsci.2018.387.400

Table 4: Genes associated with CHO DG44-HEK293 S/MAR isolated using LIS that located at intergene

\begin{tabular}{|c|c|c|c|c|c|}
\hline Flanking genes & S/MAR ID & Protein coded & Protein function & Source & Position \\
\hline MEIS2 & $\begin{array}{l}\text { S/MAR_HC_L_T } \\
\text { ER01_a }\end{array}$ & $\begin{array}{l}\text { Homeobox } \\
\text { protein Meis2 }\end{array}$ & $\begin{array}{l}\text { Interacting with DNA sequence } \\
\text { that is in cis with and relatively } \\
\text { close to a core promoter for } \\
\text { RNA polymerase II }\end{array}$ & Yang et al. (2000) & $\begin{array}{l}60 \mathrm{~kb} \text { from } 5 \text { ' end of } \\
\text { MEIS2 and } 150 \mathrm{~kb} \\
\text { from 3' end of } \\
\text { RPS15P8 }\end{array}$ \\
\hline RPS15P8 & $\begin{array}{l}\text { S/MAR_HC_L_T } \\
\text { ER01_b }\end{array}$ & $\begin{array}{l}\text { Transmembrane and } \\
\text { coiled-coil domain } \\
\text { containing protein } 5 \mathrm{~A}\end{array}$ & & & \\
\hline ZFHX4-AS1 & $\begin{array}{l}\text { S/MAR_HC_L_T } \\
\text { ER02 }\end{array}$ & $\begin{array}{l}\text { Antisense } \\
\text { RNAl }\end{array}$ & $\begin{array}{l}\text { Non-protein coding and belongs } \\
\text { to class of antisense RNA }\end{array}$ & NCBI & $\begin{array}{l}16 \mathrm{~kb} \text { from } \mathrm{ZFHX} 4- \\
\text { AS1 }\end{array}$ \\
\hline SUPTH16HP & $\begin{array}{l}\text { S/MAR_HC_L_T } \\
\text { ER03_a }\end{array}$ & $\begin{array}{l}\text { Ty16 homolog } \\
\text { S. Cerevisiae } \\
\text { pseudogene }\end{array}$ & $\begin{array}{l}\text { Interact specifically with histone } \\
\mathrm{H} 2 \mathrm{~A} / \mathrm{H} 2 \mathrm{~B} \text { to effect nucleosome } \\
\text { disassembly to facilitate } \\
\text { transcription elongation }\end{array}$ & $\begin{array}{l}\text { Orphanides et al. } \\
\text { (1999) }\end{array}$ & $\begin{array}{l}50 \mathrm{~kb} \text { from } 3^{\prime} \text { end of } \\
\text { SUPTH16HP and } 50 \\
\mathrm{~kb} \text { from 3' end of } \\
\text { GOT2P4 }\end{array}$ \\
\hline GOT2P4 & $\begin{array}{l}\text { S/MAR_HC_L_T } \\
\text { ER03_b }\end{array}$ & $\begin{array}{l}\text { Glutamicoxaloacetic } \\
\text { transaminase } 2 \text { pseudogene } 4\end{array}$ & Pseudogene & & \\
\hline $\begin{array}{l}\text { Putative gene } \\
\text { (LOC100505985) }\end{array}$ & $\begin{array}{l}\text { S/MAR_HC_L_T } \\
\text { ER04 }\end{array}$ & - & Belongs to class of lncRNA & www.genecards.com & $\begin{array}{l}5 \text { ' end of LOC1005 } \\
05985 \text { (putative gene) }\end{array}$ \\
\hline MIR2113 & $\begin{array}{l}\text { S/MAR_HC_L_T } \\
\text { ER05_a }\end{array}$ & $\begin{array}{l}\text { MicroRNA } \\
2113\end{array}$ & $\begin{array}{l}\text { Short nucleotide (20-24 nt) that } \\
\text { involved in Posttranscriptional } \\
\text { regulation and gene expression } \\
\text { in multicellular organism by } \\
\text { affecting stability and } \\
\text { translational mRNA }\end{array}$ & NCBI & $\begin{array}{l}206 \mathrm{~kb} \text { from } 3^{\prime} \text { end of } \\
\text { LOC101927314 and } \\
109 \mathrm{~kb} \text { from } 5^{\prime} \text { end of } \\
\text { MIR2113 }\end{array}$ \\
\hline $\begin{array}{l}\text { Putative gene } \\
\text { (LOC101927314) }\end{array}$ & $\begin{array}{l}\text { S/MAR_HC_L_T } \\
\text { ER05_b }\end{array}$ & - & - & & \\
\hline $\begin{array}{l}\text { Putative gene } \\
\text { (LOC100505498) }\end{array}$ & $\begin{array}{l}\text { S/MAR_HC_L_T } \\
\text { ER06_a }\end{array}$ & - & - & & $\begin{array}{l}36 \mathrm{~kb} \text { from } 3^{\prime} \text { end of } \\
\text { RPL6P5 and } 118 \mathrm{~kb} \\
\text { from 5' end of } \\
\text { LOC } 100505498\end{array}$ \\
\hline RPL6P5 & $\begin{array}{l}\text { S/MAR_HC_L_T } \\
\text { ER06_b }\end{array}$ & $\begin{array}{l}\text { Ribosomal protein L6 } \\
\text { pseudogene } 5\end{array}$ & Pseudogene & NCBI & \\
\hline $\begin{array}{l}\text { Putative gene } \\
\text { (LOC101926956) }\end{array}$ & $\begin{array}{l}\text { S/MAR_HC_L_T } \\
\text { ER07_a }\end{array}$ & - & - & & $\begin{array}{l}202 \mathrm{~kb} \text { from } 5^{\prime} \text { end of } \\
\text { LOC } 101926956 \text { and } \\
323 \mathrm{~kb} \text { from } 5^{\prime} \text { end of } \\
\text { RPS26P10 }\end{array}$ \\
\hline RPS26P10 & $\begin{array}{l}\text { S/MAR_HC_L_T } \\
\text { ER07_b }\end{array}$ & $\begin{array}{l}\text { Ribosomal protein } \\
\text { S26 pseudogene } 10\end{array}$ & $\begin{array}{l}\text { Specifically binds to domain C of } \\
\text { Taxresponsive enhancer element } \\
\text { in long terminal repeat of human } \\
\text { T-cell leukemia virus type I (HTLV-I) }\end{array}$ & $\begin{array}{l}\text { Morita et al. } \\
\text { (1993) }\end{array}$ & \\
\hline POLD2PI & $\begin{array}{l}\text { S/MAR_HC_L_T } \\
\text { ER08_a }\end{array}$ & $\begin{array}{l}\text { Exon and gene polymerase } \\
\text { (DNA directed) delta } 2 \\
\text { accessory subunit } \\
\text { pseudogene } 2\end{array}$ & Pseudogene & NCBI & $\begin{array}{l}289 \mathrm{~kb} \text { from } 5^{\prime} \text { end of } \\
\text { POLD2PI and } 87 \mathrm{~kb} \\
\text { from 5' end of } \\
\text { CCT7P2 }\end{array}$ \\
\hline СCT7P2 & $\begin{array}{l}\text { S/MAR_HC_L_T } \\
\text { ER08_b }\end{array}$ & $\begin{array}{l}\text { Chaperonin containing TCP1 } \\
\text { subunit pseudogene } 2\end{array}$ & Pseudogene & $\mathrm{NCBI}$ & \\
\hline $\begin{array}{l}\text { Putative gene } \\
\text { (LOC100419816) }\end{array}$ & $\begin{array}{l}\text { S/MAR_HC_L_T } \\
\text { ER09_a }\end{array}$ & $\begin{array}{l}\text { Orthodontic } \\
\text { homeobox } 2 \\
\text { pseudogene }\end{array}$ & $\begin{array}{l}\text { Influence proliferation and } \\
\text { differentiation of dopaminergic } \\
\text { neuronal progenitor cell during } \\
\text { mitosis }\end{array}$ & $\mathrm{NCBI}$ & $\begin{array}{l}161 \mathrm{~kb} \text { from } 5^{\prime} \text { end of } \\
\text { LOC100419816 and } \\
121 \mathrm{~kb} \text { from 3' end of } \\
\text { RPL17P12 }\end{array}$ \\
\hline RPL17P12 & $\begin{array}{l}\text { S/MAR_HC_L_T } \\
\text { ER09_b }\end{array}$ & $\begin{array}{l}\text { Ribosomal protein } \\
\text { pseudogene } 12\end{array}$ & Pseudogene & & \\
\hline RAB5CP2 & $\begin{array}{l}\text { S/MAR_HC_L_T } \\
\text { ER10_a }\end{array}$ & $\begin{array}{l}\text { RAS oncogene family } \\
\text { pseudogene } 2\end{array}$ & Pseudogene & & $\begin{array}{l}150 \mathrm{~kb} \text { from } 3^{\prime} \text { end of } \\
\mathrm{RAB} 5 \mathrm{CP} 2 \text { and } 235 \mathrm{bp} \\
\text { from } 3^{\prime} \text { end of }\end{array}$ \\
\hline РCBP2P3 & $\begin{array}{l}\text { S/MAR_HC_L_T } \\
\text { ER10_a }\end{array}$ & $\begin{array}{l}\text { Poly }(\mathrm{rC}) \text { binding } \\
\text { protein2 pseudogene } 3\end{array}$ & Pseudogene & & РCBP2P3 \\
\hline $\begin{array}{l}\text { Putative gene } \\
\text { (LOC100419816) }\end{array}$ & $\begin{array}{l}\text { S/MAR_HC_L_T } \\
\text { ER11_a }\end{array}$ & $\begin{array}{l}\text { Orthodonticle } \\
\text { homeobox } 2 \\
\text { Pseudogene }\end{array}$ & $\begin{array}{l}\text { Influence proliferation and } \\
\text { differentiation of dopaminergic } \\
\text { neuronal progenitor } \\
\text { cell during mitosis }\end{array}$ & $\mathrm{NCBI}$ & $\begin{array}{l}101 \mathrm{~kb} \text { from } 5 \text { ' end of } \\
\text { LOC100419816 and } \\
61 \mathrm{~kb} \text { from S/MAR_- } \\
\text { HC_L_TER 09_a kb }\end{array}$ \\
\hline HIG1 & $\begin{array}{l}\text { S/MAR_HC_L_T } \\
\text { ER12_a }\end{array}$ & $\begin{array}{l}\text { Hypoxia inducible domain } \\
\text { family, member } 1 \mathrm{~A}\end{array}$ & $\begin{array}{l}\text { Involve in the assembly of } \\
\text { respiratory supercomplex }\end{array}$ & NCBI & $38 \overline{\mathrm{kb}}$ from $5^{\prime}$ end of HIGI \\
\hline $\begin{array}{l}\text { Putative gene } \\
\text { (LOC100190924) }\end{array}$ & $\begin{array}{l}\text { S/MAR_HC_L_T } \\
\text { ER13_a }\end{array}$ & $\begin{array}{l}\text { Eukaryotic translation } \\
\text { initiation factor } 4 \mathrm{E} \text { binding } \\
\text { protein pseudogene }\end{array}$ & Pseudogene & NCBI & $\begin{array}{l}175 \mathrm{~kb} \text { form } 5^{\prime} \text { end of } \\
\text { LOC100190924 and } \\
379 \mathrm{~kb} \text { from 5' end of POU3F2 }\end{array}$ \\
\hline POU3F2 & $\begin{array}{l}\text { S/MAR_HC_L_T } \\
\text { ER13_b }\end{array}$ & $\begin{array}{l}\text { Pou class } 3 \text { of neural } \\
\text { transcription factor }\end{array}$ & $\begin{array}{l}\text { Involved in neuronal } \\
\text { differentiation }\end{array}$ & www.uniprot.org & \\
\hline
\end{tabular}


Table 5: Genes associated with CHO DG44-HEK293 S/MAR isolated using LIS that located at intragene

\begin{tabular}{|c|c|c|c|c|}
\hline $\begin{array}{l}\text { Genes associated } \\
\text { with S/MAR }\end{array}$ & S/MAR ID & Protein coded & Protein function & Source \\
\hline RBM12B2 & S/MAR_HC_L_TRA01 & RNA binding protein $12 \mathrm{~B}-\mathrm{B}$ & $\begin{array}{l}\text { A protein that exhibits poly(A) } \\
\text { RNA binding (ortholog) }\end{array}$ & \\
\hline KDM6A & S/MAR_HC_L_TRA02 & $\begin{array}{l}\text { Lysine }(\mathrm{K}) \text {-specific demethylase } \\
6 \mathrm{~A}\end{array}$ & $\begin{array}{l}\text { Act as histone demethylase that } \\
\text { play a role in histone code }\end{array}$ & www.uniprot.org \\
\hline SYNCRIP & S/MAR_HC_L_TRA03 & $\begin{array}{l}\text { Synaptotagmin binding cytoplasmic } \\
\text { RNA interaction protein }\end{array}$ & Play a role in mRNA maturation & $\mathrm{NCBI}$ \\
\hline CPSF2 & S/MAR_HC_L_TRA04 & $\begin{array}{l}\text { Homo sapiens cleavage and } \\
\text { polyadenylation specific factor } 6\end{array}$ & $\begin{array}{l}\text { Involve in pre-mRNA } 3 \text { '- end } \\
\text { formation }\end{array}$ & www.uniprot.org \\
\hline $\mathrm{ZCCHC7}$ & S/MAR_HC_L_TRA05 & $\begin{array}{l}\text { Zinc finger-CCHC domain } \\
\text { containing protein } 7\end{array}$ & $\begin{array}{l}\text { Involve in gene transcription, } \\
\text { translation, mRNA trafficking, } \\
\text { cytoskeleton organization, epithelial } \\
\text { development, cell adhesion, protein } \\
\text { folding, chromatin remodeling, zinc } \\
\text { sensing }\end{array}$ & $\begin{array}{l}\text { www.ebi.ac.uk } \\
\text { (Interpro) }\end{array}$ \\
\hline RSBN1 & S/MAR_HC_L_TRA06 & Round spermatid basic protein & $\begin{array}{l}\text { Play important role in transcriptional } \\
\text { regulation in haploid germ cells }\end{array}$ & www.ebi.ac.uk \\
\hline NRXN1 & S/MAR_HC_L_TRA07 & Neuroxin 1 & $\begin{array}{l}\text { Involved in cell-cell interactions, } \\
\text { exocytosis of secretory granules and } \\
\text { regulation of signal transmission }\end{array}$ & www.uniprot.org \\
\hline RANBP17 & S/MAR_HC_L_TRA08 & RAN binding protein & $\begin{array}{l}\text { Transport of protein and large RNAs } \\
\text { Through nuclear pore complex }\end{array}$ & NCBI \\
\hline MIPOL1 & S/MAR_HC_L_TRA09 & Mirror-image polydactyly gene 1 & May function as tumor suppressor & NCBI \\
\hline FAM172A & S/MAR_HC_L_TRA10 & $\begin{array}{l}\text { Family with sequence similarity } \\
172, \text { member A }\end{array}$ & (Function not characterized yet) & - \\
\hline MATR3 & S/MAR_HC_L_TRA11 & Matrin 3 & $\begin{array}{l}\text { May play a role in transcription or } \\
\text { interact with nuclear matrix to form } \\
\text { internal fibrogranular network }\end{array}$ & www.uniprot.org \\
\hline POLA1 & S/MAR_HC_L_TRA12 & $\begin{array}{l}\text { DNA polymerase alpha } \\
\text { catalytic subunit isoform }\end{array}$ & Initiation in DNA replication & www.uniprot.org \\
\hline LRBA & S/MAR_HC_L_TRA13 & $\begin{array}{l}\text { LPS-responsive vesicle trafficking, } \\
\text { beige and achor containing protein }\end{array}$ & $\begin{array}{l}\text { Maybe involve in intracellular } \\
\text { vesicles to activated receptor complex, } \\
\text { which aids in secretion and membrane } \\
\text { deposition of immune effector molecules }\end{array}$ & NCBI \\
\hline RASAL2 & S/MAR_HC_L_TRA14 & $\begin{array}{l}\text { Homo sapiens RAS protein } \\
\text { activator like } 2\end{array}$ & $\begin{array}{l}\text { Activator of Ras superfamily of small } \\
\text { GTPase }\end{array}$ & www.genecarads.org \\
\hline EHBP1 & S/MAR_HC_L_TRA15 & EH-binding protein 1 , isoform $\mathrm{X} 4$ & (As described in S/MAR_HC_N_TRA03) & \\
\hline SRSF10 & S/MAR_HC_L_TRA16 & $\begin{array}{l}\text { Homo sapiens serine/arginine-rich } \\
\text { splicing factor } 10\end{array}$ & $\begin{array}{l}\text { Splicing factor or repressor } \\
\text { of pre-mRNA splicing }\end{array}$ & www.uniprot.org \\
\hline RANBP17 & S/MAR_HC_L_TRA17 & $\begin{array}{l}\text { Homo sapiens RAN binding } \\
\text { protein } 17\end{array}$ & (As described in S/MAR_HC_L_TRA08) & \\
\hline $\begin{array}{l}\text { ANKHD1- } \\
\text { EIF4EBP3 }\end{array}$ & S/MAR_HC_L_TR A18 & $\begin{array}{l}\text { Homo sapiens ANKHD1- } \\
\text { EIF4EBP3 readthrough }\end{array}$ & $\begin{array}{l}\text { Naturally occurring readthrough transcript } \\
\text { of neighbouring ANKHD1 and EIF4EBP3 } \\
\text { genes }\end{array}$ & \\
\hline SKAP2 & S/MAR_HC_L_TRA19 & $\begin{array}{l}\text { Src kinase-associated } \\
\text { phosphoprotein } 2\end{array}$ & $\begin{array}{l}\text { Substrate of Src family kinase and } \\
\text { involved in Src signaling pathway and } \\
\text { regulate activity of immune system }\end{array}$ & NCBI \\
\hline LRBA & S/MAR_HC_L_TRA20 & - & As described in S/MAR_HC_L_TRA13) & \\
\hline ASCC3 & S/MAR_HC_L_TRA21 & $\begin{array}{l}\text { Activating signal cointegrator } 1 \\
\text { complex subunit } 3\end{array}$ & $\begin{array}{l}\text { Member of helicase and involved in } \\
\text { repair of alkylated DNA }\end{array}$ & NCBI \\
\hline TEX41 & S/MAR_HC_L_TRA22 & $\begin{array}{l}\text { A non-coding protein known } \\
\text { as testis expressed } 41\end{array}$ & $\begin{array}{l}\text { A RNA gene affiliated with long } \\
\text { non-coding RNA class }\end{array}$ & www.uniprot.org \\
\hline DACH1 & S/MAR_HC_L_TRA23 & Dachshund homolog 1 isoform a & $\begin{array}{l}\text { Transcription factor involved in regulation } \\
\text { of organogenesis }\end{array}$ & www.uniprot.org \\
\hline EHBP1 & S/MAR_HC_L_TRA24 & EH domain binding protein 1 & (As described in S/MAR_HC_N_TRA03) & $\mathrm{NCBI}$ \\
\hline UCKL1 & S/MAR_HC_L_TRA25 & $\begin{array}{l}\text { Homo sapiens uridinecytidine } \\
\text { kinase } 1 \text {-like } 1\end{array}$ & $\begin{array}{l}\text { Catalyze phosphorylation of urudine to } \\
\text { uridine monophosphate as part of } \\
\text { ribonucleotide salvage pathway }\end{array}$ & \\
\hline
\end{tabular}

To characterize these $44 \mathrm{HEK} / \mathrm{CHO}$ shared S/MARs in respect of their position in the genome, the consensus sequences were mapped against the human reference genome using CLC Genomic Workbench software. All six of the shared S/MARs isolated using the $\mathrm{NaCl}$ method are intragenic (Table 3), while 13 out of 38 HEK293-CHO DG44 S/MAR isolated using LIS method were at intergenic positions or located in between genes (Table 4) and the rest are intragenic (Table 5). As reported by several studies, intergenic S/MAR are usually involved in gene activation, particularly for those positioned at the upstream of a gene (Agarwal et al., 1998). Overall, most of the 44 shared S/MAR sequences have sequence similarities with protein binding, RNA binding protein, transcription factor, DNA polymerase, matrin and microRNA, in which putatively, they may involved in gene transcription. For example, three of the genes encodes for EH domain binding protein and another two encodes for RAN binding protein. Two genes that are related to RNA binding protein are SYNCRIP gene (synaptotagmin binding cytoplasmic RNA interacting protein) and RBM12B2. Two of the 
LIS-isolated S/MARs are located intergenically with poly(RC) binding protein pseudogene and initiation factor $4 \mathrm{E}$ binding protein. Other than protein binding property, three of the S/MAR HEK293-CHO DG44 has matched sequence with genes coding for transcription factor such as SOX6, DACH1 and POU3F2. ZFP62 and $\mathrm{CCHC}$ are two genes that codes for zinc finger protein. Two of the shared S/MARs have sequence matching the gene for matrin, one of the major components in nuclear matrix protein that play a role in transcription or binding of S/MAR to nuclear matrix (Lewis and Laemmli, 1982). Two shared S/MARs that are associated with initiation of replication because one of them has matches the DNA Polymerase (POLA1) gene and another is located adjacent to polymerase delta 2 gene.

We further analyzed all consensus S/MARs (from both cell types and from both methods) by performing BLASTX analysis to determine whether our S/MARs are protein-coding genes based on their sequences. S/MARs from HEK293 cells were BLASTXed against an annotated human genome database (GRCh37.p13); those from CHO DG44 cells were BLASTXed against the $\mathrm{CHO}$ $\mathrm{K} 1$ genome, since the CHO DG44 database is still under development. HEK293 S/MARs by the $\mathrm{NaCl}$ method produced $6.7 \%(624,001 / 9,291,331)$ sequences that fall in coding regions, while for $\mathrm{CHO}$ DG44 $\mathrm{NaCl}$ S/MARs the figure was only $1.2 \%(88,859 / 7,204,348)$. For LISgenerated S/MARs, the corresponding figures were $9.6 \%$ $(836,758 / 8,736,261)$ and $0.9 \%(44,049 / 4,672,913)$, for HEK and CHO cells, respectively.

\section{Discussion}

Since 1974, scientists have been trying to isolate interacting complexes between DNA and nuclear proteins, but it has been shown that the choice of isolation method used greatly affects the protein composition of the recovered (matrix or scaffold) material (Earnshaw and Laemmli, 1983). Both LIS and $\mathrm{NaCl}$ are the main component to dissociate histone from holding the densely packed chromatin causing the chromatin to loose up while leaving a halo structure poised by S/MAR that interacting with protein matrix. The principle behind $2 \mathrm{M} \mathrm{NaCl}$ or high salt isolation method is to alter ratio of anion to cation concentration between DNA and histone. The increased amount of positive ions by $\mathrm{NaCl}$ has created a competitive binding with negatively charged $\mathrm{H} 1$ histone against binding site on the chromation causing the $\mathrm{H} 1$ histone to dissociate from chromatin (Guo and Cole, 1989). LIS, on the other hand, acts as lithium acid salt that created a low ionic strength to cell environment (Gavin et al., 1998). Low ionic strength ambient has influenced DNA structure to become stiff because the presence of negative ions stimulate repulsive force among molecules of phosphate group on DNA chain until the chain stretched up thus changed the structure causing histone to dissociate from chromatin (Marky and Manning, 1991).

Linnemann et al. (2009) compared the two $\mathrm{NaCl}$ and LIS methods for S/MAR isolation to study any differences of the isolated S/MAR on the aspect of function and their role in changing genome structure associated with gene expression. The study reported that $\mathrm{NaCl}$ isolated-S/MARs were likely to be apart from the genes condensed regions, which most of them were located at the telomeric regions, whereas LIS isolatedS/MARs are mostly at the 5' end of active genes. However, the S/MAR distribution in the study only focused on five chromosomes of HeLa S3 cell line.

To explore the distribution and sequence features of $\mathrm{S} / \mathrm{MARs}$ within a genome, several studies have been conducted involving different techniques such as Southern blotting, MAR-PCR array and in silico prediction by computational software (Dijkwel and Hamlin, 1988; Rudd et al., 2004; Tachiki et al., 2009). A total of 7,535 S/MAR sequences have been generated using SOLID sequencing and, of these, 95\% contain the ORI sequence motif and $3 \%$ are located within 100 bp downstream of a transcription initiation site (Pathak et al., 2014). The experimental design is almost the same as our study except that the S/MARs were obtained from Drosophila melanogaster embryonic cells through a modified method using combination of DNase I, detergent and salt to extract the nuclear matrix prior to high salt treatment to isolate S/MARs.

In our study, we used the two original methods for $\mathrm{S} / \mathrm{MAR}$ isolation, the LIS and the $\mathrm{NaCl}$ methods. In order to provide information on S/MAR sequences that are interacting with matrix protein, we have run BLASTN analysis of S/MAR and loop DNA fractions. For both HEK293 and CHO DG44 extracted using both methods, we found a very low proportion (0.07-0.32\%) of sequences co-present in both S/MAR (attached) and loop (non-attached) fractions. These co-present sequences are probably due to differences in cell cycle stages when the isolation procedure was done and reflect the dynamic nature of matrix attachments (Barboro et al., 2012; Berezney et al., 1995).

The ability of S/MARs to increase transgene expression makes them potentially useful to the biotechnology industry, particularly in biopharmaceutical applications. Thus, the choice of HEK293 and CHO DG44 cell lines used is based on their application as "workhorses" for mammalian-based biofactory production of vaccines and therapeutic proteins (Jayapal et al., 2007). Interestingly, though, S/MAR characteristics are conserved across species (Bode et al., 2006). For example, S/MARs from human showed the same insulating effect on transgene expression in other organisms such as Drosophila melanogaster. Other research has shown that a $\kappa$ intronic 
S/MAR can be replaced by another S/MAR from genomic location yet still show the same methylation pattern and normal gene expression (Namciu et al., 1998). These findings suggest that the same S/MARs may be applicable across multiple cell types, species and genes. Our study, found a total of 17.4 and 11.9 million S/MARs from HEK293 and CHO DG44, cells respectively, but, we have focused on the 44 sequences in common between the two cell types. The presence of these sequences across two different cell types from two species suggests that they might be usefully incorporated in expression vectors in a variety of mammalian cell systems.

S/MARs are believed to act by controlling transcription of the gene (or transgene) regardless of its position in the host genome (Poljak et al., 1994). A strong interaction between $\mathrm{S} / \mathrm{MARs}$ matrix proteins results in the formation of a chromatin loop, which isolates the gene flanked by the S/MARs from adjacent silencing regions (Wang et al., 2010). The S/MARmatrix binding site becomes the assembly site for transcription machinery including transcription factors and DNA polymerase (Heng et al., 2004; Ottaviani et al., 2008). S/MARs isolated using LIS usually occur either upstream or downstream of a gene and are involved in active gene expression. Conversely, S/MARs isolated using $\mathrm{NaCl}$ tend to lie in gene-poor regions and are usually associated with gene silencing (Linnemann et al., 2009). In order to investigate the function and potential utility of the 44 S/MARS shared between HEK CHO cells, we mapped them against the human genome to determine their positions relative to nearby genes. All six shared sequences isolated using the $\mathrm{NaCl}$ method are intragenic, which corresponds with the findings of with Agarwal et al. (1998). This result shows that the way $\mathrm{S} / \mathrm{MARs}$ bind to matrix protein are not certain to specific sequences but rely mostly on cell type and cell cycle stage (Boulikas, 1995). Even if S/MARs are located away from the flanked gene, S/MARs are able to bind to matrix protein and could regulate gene expression in sequential manner (Forrester et al., 1994).

Hence, in this study, we have narrowed our focus to the intergenic S/MARs. Of the 13 intergenic S/MARs isolated using LIS method, we have identified 22 neighbouring genes that reside within 0 to $382 \mathrm{~kb}$ of the S/MAR. Four of the intergenic S/MARs are not shown in pair of their neighbouring genes because they are located too far from S/MARs (above $400 \mathrm{~kb}$ away). From the 22 neighbouring genes, seven of them lie within $100 \mathrm{~kb}$ of the S/MAR; of these seven, two are involved in transcription, three are pseudogenes, one encodes and antisense RNA and one is immediately adjacent to a putative non-coding RNA gene. A further eight of the 22 neighboring genes are lie between 100 and $200 \mathrm{~kb}$ from the S/MAR; six of these are pseudogenes, one encodes a transmembrane and coiled-coil domain protein and one encodes a microRNA (Table 4). Lastly, there are seven neighbouring genes that located between 200 and $300 \mathrm{~kb}$ from S/MAR; five of them are pseudogenes, one is involved in respiratory supercomplex assembly and another is a transcription factor involved in neruronal differentiation. Those S/MARs, which are adjacent to genes involved in transcription, might be of interest as gene expression regulators; however, further experiments are needed to test this.

In agreement with the previously reported characteristics of S/MARs (Girod et al., 2005), we found very few that lay within coding sequences (through the BLASTX analysis). This agrees with the supposed role of S/MARs in creating gene-containing chromatin domains to either facilitate or repress transcription (Namciu et al., 1998; Ma et al., 1999).

Future studies will benefit from the completion of the CHO DG44 genome database, against which we will be able to map the S/MARs isolated in this study and we hope to create a S/MAR database once the DG44 database is available. We also hope to test the function of some of these S/MARs in promoting transgene transcription from vectors in mammalian cells.

\section{Conclusion}

S/MARs, as DNA elements that determine chromatin organization and regulate gene expression, have been exploited as vector expression elements that can stabilize expression in mammalian cell host systems. However, the S/MARs we have isolated in this study need further evaluation in this capacity. An interaction study between our S/MAR sequences and matrix proteins, especially in vivo, would help us to understand the function of individual S/MARs in cells and how this relates to cell cycle and gene expression. We plan to further investigate the behaviour of our S/MARs via molecular docking with matrix proteins as well as by performing biophysical and biochemical analysis of the cells during the interactions. Finally, our main target is to capture the interaction of S/MARs and matrix proteins and to perform the analysis through live cell imaging. In the meantime, the effect of incorporating the S/MARs we have identified into expression vectors is our main priority in order to confirm their capability in enhancing recombinant protein production by overcoming transgene silencing caused by positional effect.

\section{Acknowledgement}

We would like to thanks Ministry of Higher Education Malaysia (FRGS/2011/SG/UKM/03/7) for funding this research. Thanks to Dr. Heilly Chong and the staff of Protein Science Department, Inno Biologics Sdn. Bhd. for providing the cell lines. Thanks to the School of Bioscience and Biotechnology, Faculty of Science and Technology, 
Universiti Kebangsaan Malaysia and Malaysia Genome Institute for materials, facilities and technical supports. Thank you to Mr. Mohammad Faizal for assisting in bioinformatics analysis, Dr. Norazfa for technical assistance in halo in gel method and also to Dr. Paul H. Dear for proofreading this paper.

\section{Funding Information}

This manuscript is funded by Ministry of Higher Education Malaysia (FRGS/2011/SG/UKM/03/7).

\section{Author's Contributions}

Nur Shazwani Mohd Pilus: Drafted and wrote the manuscript, performed the experiment and result analysis.

Azrin Ahmad: Assisted in bioinformatic analysis on the CHO genome annotation.

Nurul Yuziana Mohd Yusof: Initiated the idea of S/MAR study, supervised the experiment's progress, result interpretation and helped in manuscript preparation.

\section{Ethics}

There are no ethical issues after the publication of this manuscript.

\section{References}

Agarwal, M., T.W. Austin, F. Morel, J. Chen, E. Böhnlein and I. Plavec, 1998. Scaffold attachment region-mediated enhancement of retroviral vector expression in primary T cells. J. Virol., 72: 3720-3728. PMID: 9557654

Ahmad, A., 2016. Genomic and transcriptomic analysis of CHO DG44 cell lines using next generation sequencing approach. MSc Thesis, School of Bioscience and Biotechnology, Universiti Kebangsaan Malaysia.

Allen, G.C., S. Spiker and W.F. Thompson, 2005. Transgene Integration: Use of Matrix Attachment Regions. In: Transgenic Plants: Methods and Protocols, Peña, L. (Ed.), Springer, Totowa, ISBN-10: 1592598277, pp: 313-326.

Argyros, O., S.P. Wong, C. Fedonidis, O. Tolmachov and S.N. Waddington et al., 2011. Development of S/MAR minicircles for enhanced and persistent transgene expression in the mouse liver. J. Molecular Med., 89: 515-529.

DOI: $10.1007 / \mathrm{s} 00109-010-0713-3$

Barboro, P., E. Repaci, C. D'arrigo and C. Balbi, 2012. The role of nuclear matrix proteins binding to matrix attachment regions (Mars) in prostate cancer cell differentiation. PLoS One, 7: e40617-e40617.

DOI: 10.1371/journal.pone.0040617
Berezney, R. and D.S. Coffey, 1974. Identification of a nuclear protein matrix. Biochem. Biophys. Res. Commun., 620: 1410-1417. DOI: $10.1016 / 0006-291 X(74) 90355-6$

Berezney, R., M.J. Mortillaro, H. Ma, X. Wei and J. Samarabandu, 1995. The nuclear matrix: A structural milieu for genomic function. Int. Rev. Cytol., 162A: 1-65. PMID: 8575878

Bode, J., C. Benham, E. Ernst, A. Knopp and R. Marschalek et al., 2000. Fatal connections: When DNA ends meet on the nuclear matrix. J. Cell Biochem. Suppl. Suppl., 35: 3-22. PMID: 11389527

Bode, J. and K. Maass, 1988. Chromatin domain surrounding the human interferon-. beta. Gene as defined by scaffold-attached regions. Biochemistry, 27: 4706-4711. DOI: 10.1021/bi00413a019

Bode, J., T. Schlake, M. Rios-Ramirez, C. Mielke and M. Stengert et al., 1996. Scaffold/matrix-attached regions: Structural properties creating transcriptionally active loci. Int. Rev. Cytol., 162: 389-454. DOI: 10.1016/S0074-7696(08)61235-8

Bode, J., S. Winkelmann, S. Götze, S. Spiker and K. Tsutsui et al., 2006. Correlations between Scaffold/Matrix Attachment Region (S/MAR) binding activity and DNA duplex destabilization energy. J. Molecular Biol., 358: 597-613. DOI: $10.1016 /$ j.jmb.2005.11.073

Boulikas, T., 1995. Chromatin domains and prediction of MAR sequences. Int. Rev. Cytol., 162A: 279-388. DOI: 10.1016/S0074-7696(08)61234-6

Chomczynski, P. and N. Sacchi, 1987. Single-step method of RNA isolation by acid guanidinium thiocyanate-phenol-chloroform extraction. Analytical Biochem., 162: 156-159. DOI: 10.1016/0003-2697(87)90021-2

Cockerill, P.N. and W.T. Garrard, 1986. Chromosomal loop anchorage of the kappa immunoglobulin gene occurs next to the enhancer in a region containing topoisomerase II sites. Cell, 44: 273-282.

DOI: 10.1016/0092-8674(86)90761-0

Dijkwel, P.A. and J.L. Hamlin, 1988. Matrix attachment regions are positioned near replication initiation sites, genes and an interamplicon junction in the amplified dihydrofolate reductase domain of Chinese hamster ovary cells. Mol. Cell Biol., 8: 5398-5409. DOI: 10.1128/MCB.8.12.5398

Donev, R.M., 2000. The type of DNA attachment sites recovered from nuclear matrix depends on isolation procedure used. Mol. Cell Biochem., 214: 103-110. DOI: $10.1023 / \mathrm{A}: 1007159421204$

Earnshaw, W.C. and U.K. Laemmli, 1983. Architecture of metaphase chromosomes and chromosome scaffolds. J. Cell Biol., 96: 84-93. DOI: 10.1083/jcb.96.1.84 
Feng, Y.Q., M.C. Lorincz, S. Fiering, J.M. Greally and E.E. Bouhassira, 2001. Position effects are influenced by the orientation of a transgene with respect to flanking chromatin. Mol. Cellular Biol., 21: 298-309. DOI: 10.1128/MCB.21.1.298-309.2001

Forrester, W.C., C. Van Genderen, T. Jenuwein and R. Grosschedl, 1994. Dependence of enhancermediated transcription of the immunoglobulin mu gene on nuclear matrix attachment regions. Science, 265: 1221-1225. DOI: 10.1126/science.8066460

Gavin, I.M., S.I. Usachenko and S.G. Bavykin, 1998. Nucleosome structural transition during chromatin unfolding is caused by conformational changes in nucleosomal DNA. J. Biol. Chem., 273: 2429-2434. DOI: $10.1074 /$ jbc.273.4.2429

Girod, P.A., M. Zahn-Zabal and N. Mermod, 2005. MAR elements as tools to increase protein production by CHO cells. In: Animal Cell Technology Meets Genomics, Gòdia, F. and M. Fussenegger (Eds.), Springer, Dordrecht, pp: 411-415.

Guo, X. and R.D. Cole, 1989. Chromatin aggregation changes substantially as $\mathrm{pH}$ varies within the physiological range. J. Biol. Chem., 264: 11653-11657.

Heng, H.H., S. Goetze, C.J. Ye, G. Liu and J.B. Stevens et al., 2004. Chromatin loops are selectively anchored using scaffold/matrixattachment regions. J. Cell Sci., 117: 999-1008. DOI: 10.1242/jcs.00976

Jackson, D.A., 1997. Chromatin domains and nuclear compartments: Establishing sites of gene expression in eukaryotic nuclei. Molecular Biol. Rep., 24: 209-220. DOI: 10.1023/A:1006873614521

Jayapal, K.P., K.F. Wlaschin, W. Hu and M.G. Yap, 2007. Recombinant protein therapeutics from $\mathrm{CHO}$ cells-20 years and counting. Chem. Eng. Progress, 103: 40-40.

Keaton, M.A., C.M. Taylor, R.M. Layer and A. Dutta, 2011. Nuclear scaffold attachment sites within ENCODE regions associate with actively transcribed genes. PLoS One, 6: e17912-e17912. DOI: $10.1371 /$ journal.pone.0017912

Krawetz, S.A., S. Draghici, R. Goodrich, Z. Liu and G.C. Ostermeier, 2005. In silico and wet-bench identification of nuclear matrix attachment regions. Meth. Mol. Med., 108: 439-458. PMID: 16028699

Lewis, C.D. and U.K. Laemmli, 1982. Higher order metaphase chromosome structure: evidence for metalloprotein interactions. Cell, 29: 171-181. DOI: 10.1016/0092-8674(82)90101-5

Linnemann, A.K., A.E. Platts and S.A. Krawetz, 2009. Differential nuclear scaffold/matrix attachment marks expressed genes. Hum. Mol. Genet., 18: 645-654. DOI: $10.1093 / \mathrm{hmg} / \mathrm{ddn} 394$

Ma, H., A.J. Siegel and R. Berezney, 1999. Association of chromosome territories with the nuclear matrix. Disruption of human chromosome territories correlates with the release of a subset of nuclear matrix proteins. J. Cell Biol., 146: 531-542.

DOI: $10.1083 /$ jcb.146.3.531
Manuelidis, L., 1990. A view of interphase chromosomes. Science, 250: 1533-1540. PMID: 2274784

Marky, N.L. and G.S. Manning, 1991. The elastic resilience of DNA can induce all-or-none structural transitions in the nucleosome core particle. Biopolymers, 31: 1543-1557. DOI: 10.1002/bip.360311310

Mirkovitch, J., M.E. Mirault and U.K. Laemmli, 1984. Organization of the higher-order chromatin loop: Specific DNA attachment sites on nuclear scaffold. Cell, 39: 223-232. DOI: $10.1016 / 0092-8674(84) 90208-3$

Morita, T., T. Sato, H. Nyunoya, A. Tsujimoto and J. Takahara et al., 1993. Isolation of a cDNA clone encoding DNAbinding protein (TAXREB107) that binds specifically to domain $\mathrm{C}$ of the tax-responsive enhancer element in the long terminal repeat of human T-cell leukemia virus type I. AIDS Res. Human Retroviruses, 9: 115-121. DOI: 10.1089/aid.1993.9.115

Namciu, S.J., K.B. Blochlinger and R.E. Fournier, 1998. Human matrix attachment regions insulate transgene expression from chromosomal position effects in Drosophila melanogaster. Mol. Cell. Biol., 18: 2382-2391. DOI: 10.1128/MCB.18.4.2382

Orphanides, G., W.H. Wu, W.S. Lane, M. Hampsey and D. Reinberg, 1999. The chromatin-specific transcription elongation factor FACT comprises human SPT16 and SSRP1 proteins. Nature, 400: 284-288. DOI: $10.1038 / 22350$

Ottaviani, D., E. Lever, P. Takousis and D. Sheer, 2008. Anchoring the genome. Genome Biol., 9: 201-201. DOI: $10.1186 / \mathrm{gb}-2008-9-1-201$

Pathak, R.U., A. Srinivasan and R.K. Mishra, 2014. Genome-wide mapping of matrix attachment regions in Drosophila melanogaster. BMC Genom., 15: 1022-1022. DOI: 10.1186/1471-2164-15-1022

Poljak, L., C. Seum, T. Mattioni and U.K. Laemmli, 1994. SARs stimulate but do not confer position independent gene expression. Nucleic Acids Res., 22: 4386-4394. DOI: 10.1093/nar/22.21.4386

Quinlan, A.R., R.A. Clark, S. Sokolova, M.L. Leibowitz and Y. Zhang et al., 2010. Genome-wide mapping and assembly of structural variant breakpoints in the mouse genome. Genome Res., 20: 623-635. DOI: $10.1101 /$ gr. 102970.109

Razin, S.V., 2001. The nuclear matrix and chromosomal DNA loops: Is their any correlation between partitioning of the genome into loops and functional domains? Cellular Mol. Biol. Lett., 6: 59-70. PMID: 11544631

Rudd, S., M. Frisch, K. Grote, B.C. Meyers and K. Mayer et al., 2004. Genome-wide in silico mapping of scaffold/matrix attachment regions in Arabidopsis suggests correlation of intragenic scaffold/matrix attachment regions with gene expression. Plant Physiol., 135: 715-722.

DOI: $10.1104 / p p .103 .037861$ 
Sumer, H., J.M. Craig, M. Sibson and K.H.A. Choo, 2003. A rapid method of genomic array analysis of Scaffold/Matrix Attachment Regions (S/MARs) identifies a 2.5-Mb region of enhanced scaffold/matrix attachment at a human neocentromere. Genome Res., 13: 1737-1743. DOI: $10.1101 /$ gr.1095903

Tachiki, K., Y. Kodama, H. Nakayama and A. Shinmyo, 2009. Determination of the in vivo distribution of nuclear matrix attachment regions using a polymerase chain reaction-based assay in Arabidopsis thaliana. J. Biosci. Bioeng., 108: 11-19. DOI: 10.1016/j.jbiosc.2009.02.010
Travers, A., 1993. DNA-Protein Interactions. 1st Edn., Springer, London, ISBN-10: 0412259907, pp: 180.

Wang, T.Y., J.H. Zhang, C.Q. Jing, X.J. Yang and J.T. Lin, 2010. Positional effects of the matrix attachment region on transgene expression in stably transfected CHO cells. Cell Biol. Int., 34: 141-145. DOI: $10.1042 / \mathrm{CBI} 20090017$

Yang, Y., C.K. Hwang, U.M. D'souza, S.H. Lee and E. Junn et al., 2000. Threeamino acid extension loop homeodomain proteins Meis2 and TGIF differentially regulate transcription. J. Biol. Chem., 275: 20734-20741. DOI: 10.1074/jbc.M908382199 